\title{
Kinetic Evaluation of Naphthalene Removal using Acid - Modified and Unmodified Bentonite Clay Mineral
}

\section{*10BI, C; OKOYE, IP}

\author{
Department of Pure and Industrial Chemistry,Faculty of Chemical Sciences, University of Port Harcourt, \\ P.M.B. 5323, Choba, Port Harcourt. Rivers State. Nigeria.
}

Email: zarasexcom@yahoo.com

KEYWORDS: Naphthalene, equilibrium, kinetics, sorption, acid - modified bentonite.

\begin{abstract}
Kinetic evaluation of naphthalene onto acid - modified and unmodified bentonite clay mineral was investigated by means of the effects of concentration, contact time and $\mathrm{pH}$. The amount of naphthalene adsorbed was determined spectrophotometrically. The optimum $\mathrm{pH}$ value and equilibrium contact time for the adsorption of naphthalene onto acid modified and unmodified samples were found to be 6.0 and 30 minutes, respectively. The maximum adsorption capacity $\left(\mathrm{q}_{\mathrm{m}}\right)$ for acid - modified and unmodified adsorbents was found to be $10.52 \mathrm{mg} / \mathrm{g}$ and $5.56 \mathrm{mg} / \mathrm{g}$. These values were close with the experimental data $\left(\mathrm{q}_{\mathrm{e}}\right)$ obtained from the adsorption of naphthalene onto acid - modified $(9.0 \mathrm{mg} / \mathrm{g})$ and unmodified $(4.0 \mathrm{mg} / \mathrm{g})$ adsorbents. The adsorption isotherm fitted well with Langmuir equation model for the acid - modified than the unmodified adsorbent. Kinetic evaluations of the adsorption showed that the process followed the pseudo - second - order equation model. The results obtained showed that modified bentonite clay mineral was reasonably effective adsorbent for the removal of naphthalene (organic contaminant), which is an important source for environmental pollutant. CJASEM
\end{abstract}

\section{http://dx.doi.org/10.4314/jasem.v18i1.20}

Introduction: Polycyclic aromatic hydrocarbons (PAHs) are potent atmospheric pollutants made up of chemical species with two to six fused benzene rings without heterogeneous substituent (Fetzer, 2000). Naphthalene is found in this family of PAHs. They are an important family of toxic hazardous and longpersistent environmental pollutants that have been found to be carcinogenic and mutagenic (Cabal et al., 2009). PAHs originate from natural and anthropogenic sources. Anthropogenic sources include industrial processes, crude oil refinery, incinerators, urban run-off, engine exhaust, domestic heating system, incomplete combustion of fossil fuels, coking process and smoke (Cabal et al., 2009). Natural sources are terrestrial coal deposits, forest fires and volcanic eruptions. The main sources of PAHs in surface waters are atmospheric deposition, runoff from contaminated soil and deposition from sewage discharges (Milhome et al., 2008). Most PAHs are hydrophobic with high boiling and melting points and electrochemical stability. Due to their hydrophobicity, they have low water solubility and can therefore exist and accumulate in soils or water for a long period of time (Ozer et al., 2008). The removal of these kinds of pollutants from the environment cannot be accomplished by traditional methods. It is now universally recognized that adsorption technology provides a feasible and effective method for the removal of pollutants from contaminated water resources and waste waters. Activated carbons are the most commonly used adsorbent in the adsorption process due to their high adsorption capacity, high surface area and high degree of surface reactivity; however, regeneration is difficult and expensive (Okoye and Obi, 2011). In recent years, extensive research is now focused on new, efficient, low-cost and easily obtainable natural materials such as clay materials, agricultural byproducts etc, to be used as adsorbents (Okoye and Obi, 2011; Abia et al., 2007). Clays attract attention due to the heterogeneity of their surfaces and some have been found to possess the ability to absorb ions from solutions and release them later, when the conditions change. There are about thirty different types of "pure" clays but most natural clays are mixtures of these different types, along with other weathered minerals (Ivan and Velimir, 1998). Studies have shown that natural clay is an effective adsorbent due to its efficiency, low cost and availability. The adsorption capabilities of natural clay are attributable to their high surface area and exchange capacities including the presence of negative charges on the clay mineral structure which can attract positively charged metal ions. 
This work is aimed at investigating the potentiality of acid - modified bentonite clay mineral in the removal of naphthalene, an organic pollutant from aqueous solution.

Kinetic evaluations were explored to ascertain the mechanism of adsorption process.

\section{MATERIALS AND METHODS}

Starting material and modification process: Acid activated bentonite was obtained by following the procedure described by Mohammed et al., (2007) and Makhoukhi et al., (2009). The commercial bentonite clay $(20 \mathrm{~g})$ was weighed and put into a round bottom flask and $200 \mathrm{ml}$ of $5 \mathrm{M} \mathrm{H}_{2} \mathrm{SO}_{4}$ was added to it to form slurry. The mixture was stirred for 30 mins with a magnetic stirrer. The mixture was heated in a water bath and kept at temperature $80^{\circ} \mathrm{C}$ and refluxed for 2 hrs. The mixture was left to cool, filtered and the residue was washed severally with de-ionized water to remove sulphate ions completely from the activated clay. The clay was dried for $24 \mathrm{hrs}$; hence the product is acid activated bentonite clay.

Equilibrium adsorption measurement: The batch adsorption experiments were carried out with $0.1 \mathrm{~g}$ of clay samples, stirred in $50 \mathrm{ml}$ of $10-60 \mathrm{mg} / \mathrm{l}$ of naphthalene solutions of at $298 \mathrm{~K}$ for $1 \mathrm{hr}$. The $\mathrm{pH}$ of the naphthalene solutions for acid - modified and unmodified were varied from $2-12$. The effect of contact time was varied from $10-60$ mins at $298 \mathrm{~K}$ using $50 \mathrm{mg} / \mathrm{l}$ of the naphthalene solution.

In every case, the mixture was filtered and the supernatant solution collected for absorbance analysis using UV spectrophotometer at the wavelength of $219 \mathrm{~nm}$.

The metal uptake by the adsorbent at equilibrium was calculated from the following expression:

$\mathrm{q}_{\mathrm{e}}=\frac{\mathrm{C}_{0}-\mathrm{C}_{\mathrm{e}}}{\mathrm{M}} \times \mathrm{V}$

Where $\mathrm{q}_{\mathrm{e}}$ is the amount of organic pollutant adsorbed in $\mathrm{mg} / \mathrm{l}, \mathrm{C}_{\mathrm{o}}$ is the initial adsorbate concentration in $\mathrm{mg} / \mathrm{l}, \mathrm{C}_{\mathrm{e}}$ is the concentration after equilibrium in $\mathrm{mg} / \mathrm{l}, \mathrm{V}$ is the total volume of solution in liter and $\mathrm{M}$ is the mass of clay sample (adsorbent) used in $\mathrm{g}$.

\section{RESULTS ANS DISSCUSSION}

Effect of Initial Organic Pollutant Concentration: The equilibrium adsorption capacities of naphthalene on acid - modified and unmodified bentonite clay minerals at constant temperature of $298 \mathrm{~K}$ are represented in Fig. 1.

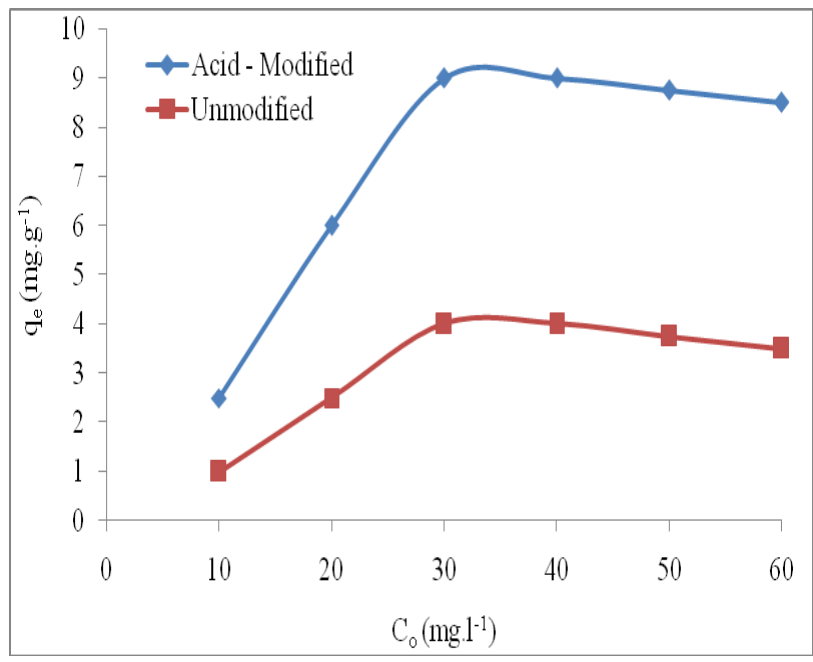

Fig 1: Effect of concentration on the removal of naphthalene at $298 \mathrm{~K}$

The result revealed that the adsorption capacities of both modified and unmodified increased steadily with naphthalene concentration. This can be attributed to the increase in the concentration gradient which acted as a driving force for the adsorption process. The optimum adsorption capacity was observed at the concentration of $30 \mathrm{mg} / \mathrm{l}$ for both adsorbents. However, the increase in adsorption capacity became less significant above $30 \mathrm{mg} / \mathrm{l}$. This is probably as a result of saturation at the active sites of modified and unmodified samples. The result further showed that the adsorption capacity obtained for acid - modified sample, $10.52 \mathrm{mg} \mathrm{g}^{-1}$ was higher than that of unmodified sample, $5.56 \mathrm{mg} \mathrm{g}^{-1}$. This could be attributed to the presence of acid sites on the modified clay sample or increase in pore size/volume.

Effect of solution $p H$ : The effect of $\mathrm{pH}$ on the removal of naphthalene by acid - modified and unmodified bentonite clay minerals from aqueous solution is represented in Fig. 2. 


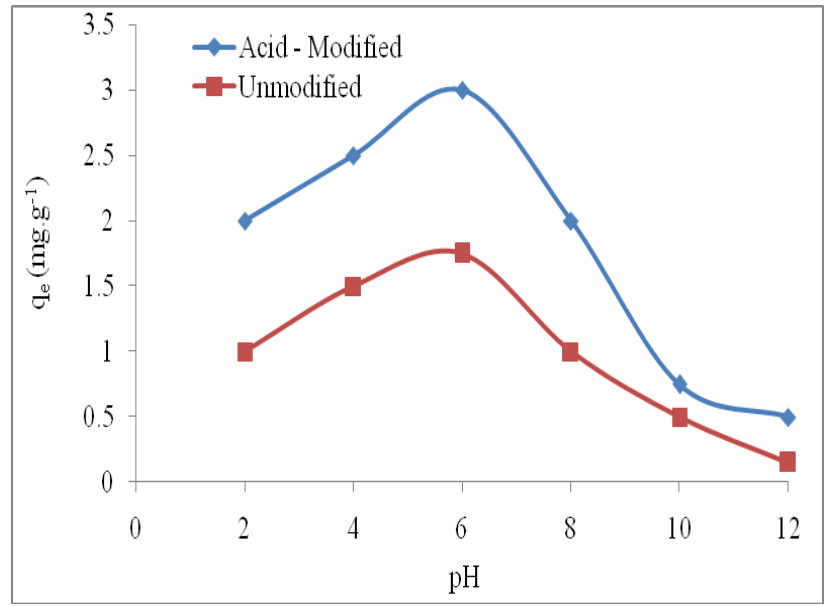

Fig 2: Effect of $\mathrm{pH}$ on the removal of naphthalene at $298 \mathrm{~K}$

The result showed that maximum adsorption capacity was observed at $\mathrm{pH}$ close to the neutral values. It was observed that the adsorption process is highly dependent on the $\mathrm{pH}$ of the solution. Therefore the optimum $\mathrm{pH}$ for the sorption process is 6.0. This could be as a result of the synergistic effect of the neutral properties of naphthalene and solvent (ethanol) used in dissolution. At higher $\mathrm{pH}$ values $(8-12)$, the adsorption capacity decreased significantly. This could be as a result of saturation of the naphthalene and solvent at the solid - liquid interface.

Effect of contact time: The effect of contact time on the adsorption of naphthalene onto acid - modified and unmodified clay samples at $298 \mathrm{~K}$ is presented in Fig. 3 below:

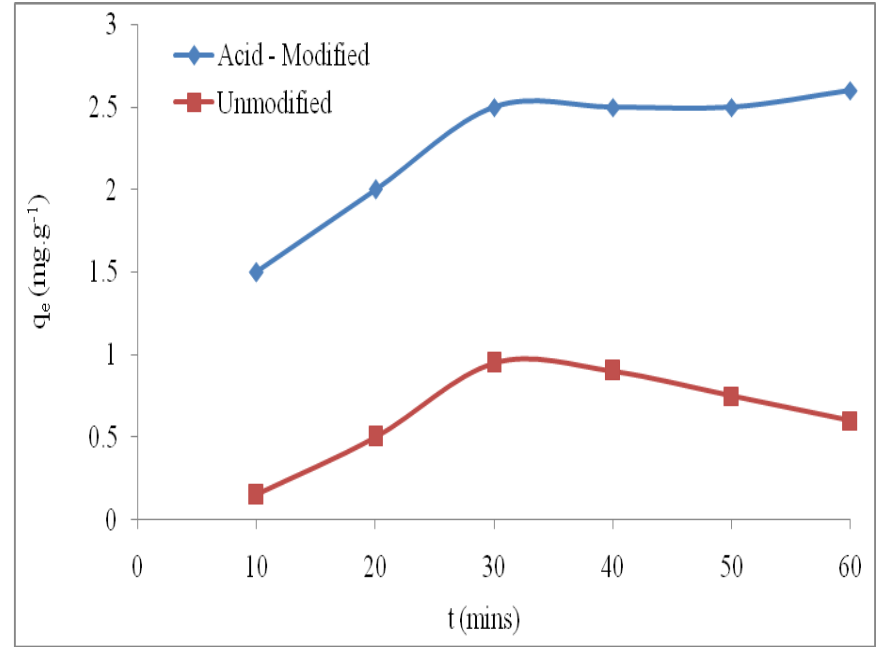

Fig: 3 Effect of contact time on the removal of naphthalene at $298 \mathrm{~K}$

Maximum adsorption capacities for both acid modified and unmodified bentonite clay samples was observed at 30 minutes, beyond which there was almost no further increase in the adsorption capacities. In order to investigate the adsorption kinetics of the adsorbate onto the adsorbents, Lagergren pseudo - first - order, pseudo - second order, Elovich and intraparticle diffusion models were applied to the experimental data. The linearized forms of the models are presented below:

Tab: 1: Showing adsorption kinetic models used in this study

\begin{tabular}{ccl}
\hline Models & Equations & References \\
\hline Lagergren first - order & In $\left(\mathrm{q}_{\mathrm{e}}-\mathrm{q}_{\mathrm{t}}\right)=\operatorname{In} \mathrm{q}_{\mathrm{e}}-\mathrm{k}_{\mathrm{l}} \mathrm{t}$ & Lagergren, 1898 \\
Pseudo - second - order & $\mathrm{t} / \mathrm{q}_{\mathrm{t}}=1 / \mathrm{k}_{2} \mathrm{q}_{\mathrm{e}}+1 / \mathrm{q}_{\mathrm{e}} \mathrm{t}$ & Ho and Mckay, 1998 \\
Elovich & $\mathrm{q}_{\mathrm{t}}=1 / \beta \operatorname{In}(\alpha, \beta)+1 / \beta$ In t & Sparks, 1999 \\
Intraparticle diffusion & $\mathrm{q}_{\mathrm{t}}=\mathrm{k}_{\mathrm{p}} \mathrm{t}^{1 / 2}+\mathrm{C}$ & Weber and Morriss, 1963 \\
\hline
\end{tabular}


Where $\mathrm{q}_{\mathrm{e}}$ and $\mathrm{q}_{\mathrm{t}}$ are amounts of adsorbed at equilibrium and at various times $\mathrm{t}\left(\mathrm{mg} \mathrm{g}^{-1}\right), \mathrm{k}_{1}$ and $\mathrm{k}_{2}$ are rate constants of the Lagergren first - order and pseudo - second - order models for the adsorption process $\left(\mathrm{mins}^{-1}\right.$ and $\mathrm{g} \mathrm{mg}^{-1} \mathrm{mins}^{-1}$ ), $\alpha$ is the initial

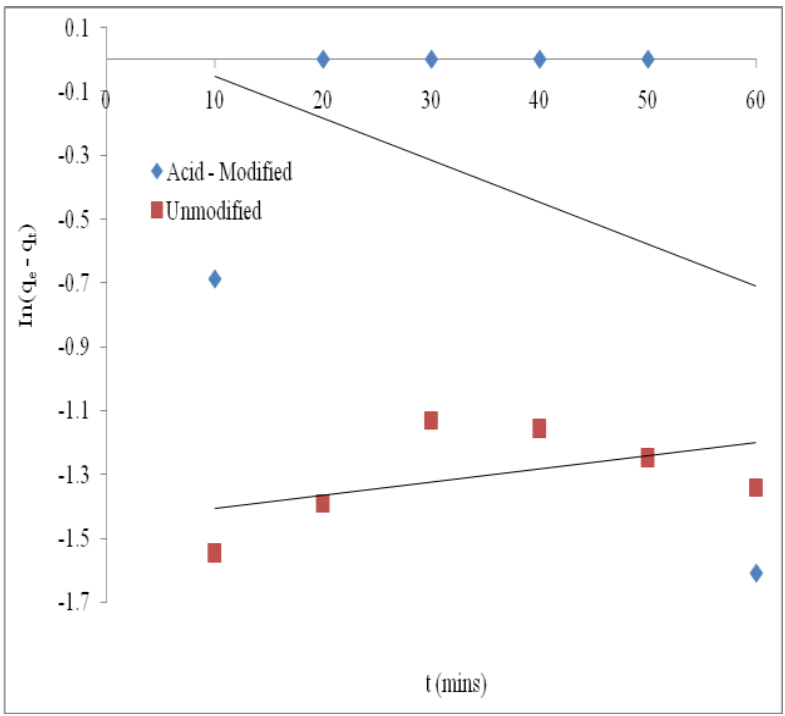

Fig 4: Lagergren first - order plots for naphthalene removal at $298 \mathrm{~K}$

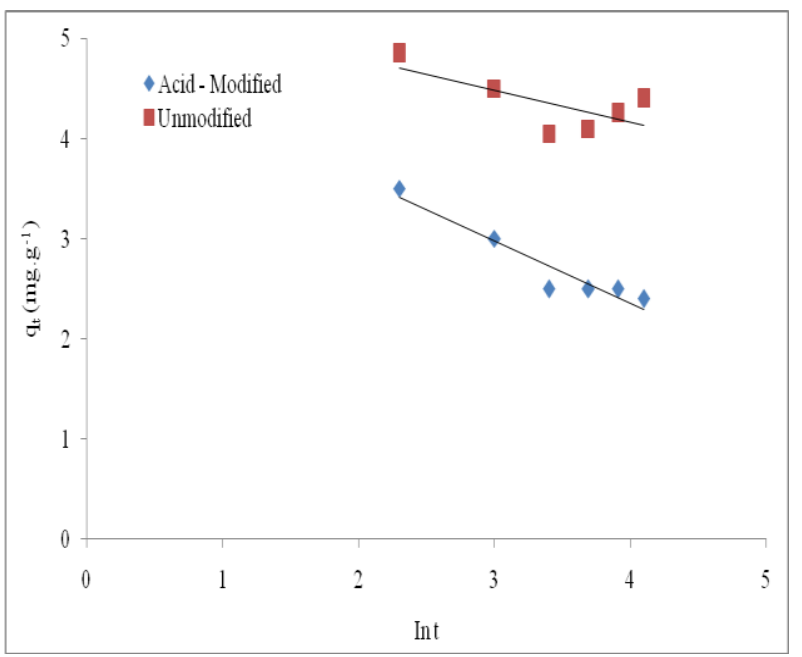

Fig 6: Elovich plot for naphthalene removal at $298 \mathrm{~K}$

The results showed that the Lagergren first - order, Elovich and intraparticle diffusion models cannot identify the mechanism of the adsorption process over modified and unmodified bentonite clay samples. On the other hand, the kinetic evaluation on the sorption properties of naphthalene fitted well with pseudo - second order model with high correlation adsorption rate $\left(\mathrm{mg} \mathrm{g}^{-1} \mathrm{mins}^{-1}\right), \beta$ is the desorption constant $\left(\mathrm{g} \mathrm{mg}^{-1}\right)$ for Elovich equation, $\mathrm{C}$ is the intercept, and $\mathrm{k}_{\mathrm{p}}$ is the intraparticle diffusion rate constant $\left(\mathrm{mg} \mathrm{g} \mathrm{g}^{-1} \operatorname{mins}^{-1 / 2}\right)$. The straight line plots of these models have been represented in Fig. 4 - 7.

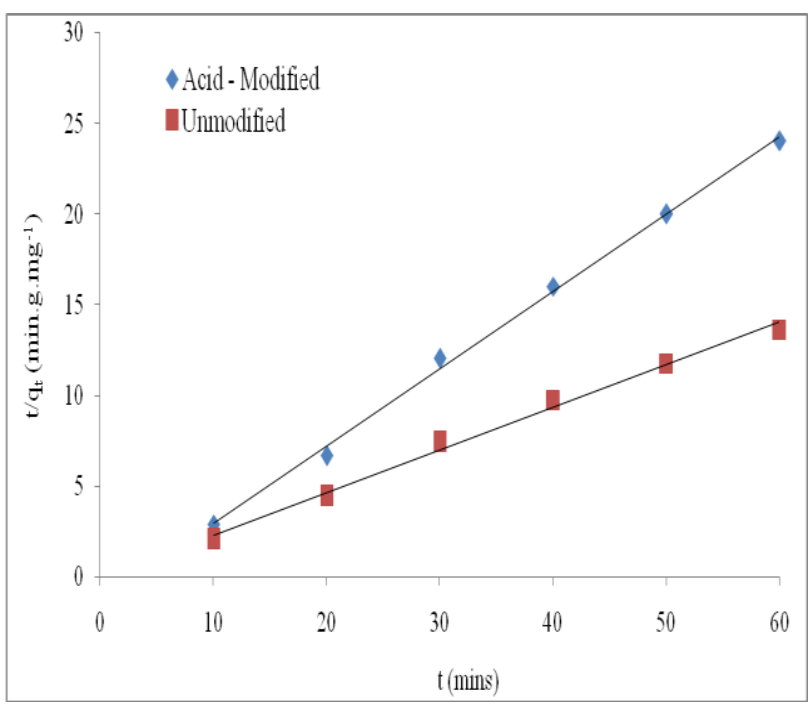

Fig 5: Pseudo - second - order plot for naphthalene removal at $298 \mathrm{~K}$

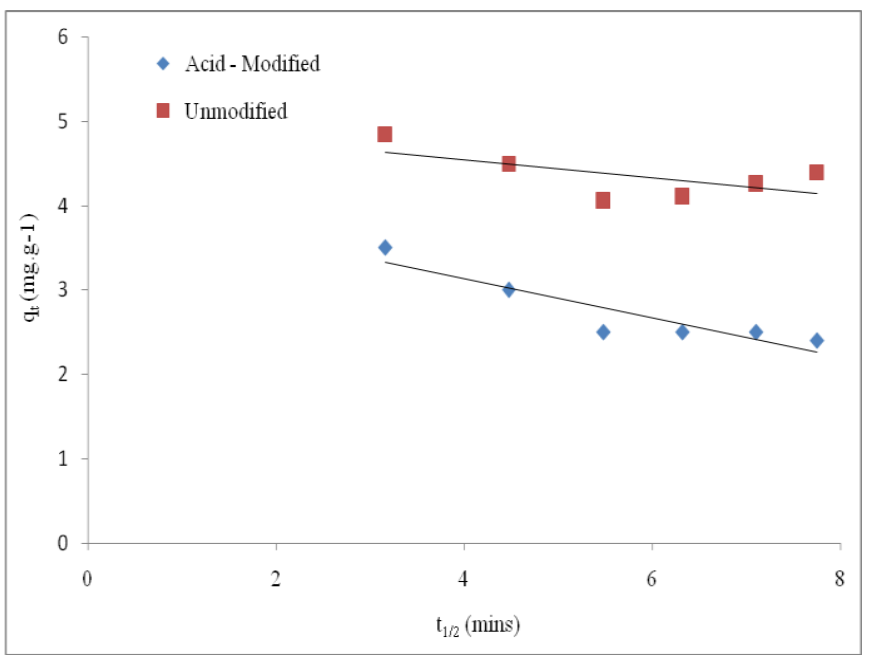

Fig 7: Intra-particle diffusion plots for naphthalene removal at $298 \mathrm{~K}$

coefficiency $\left(\mathrm{r}^{2}\right)$ of 0.997 and 0.993 for modified and unmodified bentonite clay samples. This result is similar to reports made by Cabal et al., (2009) on activated carbon. The kinetic parameters are presented in the Tab. 2 below: 
Tab. 2: Kinetic parameters for the adsorption of naphthalene onto acid - modified and unmodified bentonite at $298 \mathrm{~K}$

\begin{tabular}{|c|c|c|}
\hline Model Parameters & $\begin{array}{l}\text { Acid - Modified } \\
\text { bentonite }\end{array}$ & $\begin{array}{l}\text { Unmodified } \\
\text { bentonite }\end{array}$ \\
\hline \multicolumn{3}{|c|}{ Lagergren first - order } \\
\hline $\mathbf{k}_{1}\left(\operatorname{mins}^{-1}\right)$ & 0.01 & 0.004 \\
\hline$q_{e}\left(m g g \cdot g^{-1}\right)$ & 1.08 & 0.24 \\
\hline $\mathbf{r}^{2}$ & 0.14 & 0.24 \\
\hline \multicolumn{3}{|c|}{ Pseudo - second - order } \\
\hline $\mathrm{k}_{2}\left(\mathrm{~g} \cdot \mathrm{mg}^{-1} \cdot \mathrm{min}^{-1}\right)$ & -0.13 & -1.30 \\
\hline$q_{e}\left(m \cdot g^{-1}\right)$ & 9.45 & 4.27 \\
\hline $\mathbf{r}^{2}$ & 0.997 & 0.993 \\
\hline \multicolumn{3}{|l|}{ Elovich } \\
\hline$\alpha\left(\mathrm{mg} \cdot \mathrm{g}^{-1} \cdot \mathrm{min}^{-1}\right)$ & 127.23 & 229.30 \\
\hline$\beta\left(\mathrm{g} \cdot \mathrm{mg}^{-1}\right)$ & 1.61 & -3.16 \\
\hline $\mathbf{r}^{2}$ & 0.91 & 0.51 \\
\hline \multicolumn{3}{|c|}{ Intraparticle diffusion } \\
\hline$k_{3}\left(m g \cdot g^{-1} \cdot \min ^{1 / 2}\right)$ & -0.11 & -0.23 \\
\hline C & 5.00 & 4.10 \\
\hline $\mathbf{r}^{2}$ & 0.84 & 0.39 \\
\hline
\end{tabular}

Adsorption isotherm of the organic pollutant:

The distribution between the adsorbent and adsorbate interface at equilibrium was described by the Langmuir and Freundlich equations. These two models are widely used, the former assuming that maximum adsorption occurs when the surface is covered by adsorbate and the latter being purely empirical. The linearized forms of Langmuir and Freundlich equations are commonly presented as:

$\mathrm{C}_{\mathrm{e}} / \mathrm{q}_{\mathrm{e}}=\mathrm{C}_{\mathrm{e}} / \mathrm{q}_{\mathrm{m}}+1 / \mathrm{k}_{\mathrm{L}} \mathrm{q}_{\mathrm{m}}$

And In $\mathrm{q}_{\mathrm{e}}=$ In $\mathrm{k}_{\mathrm{F}}+1 / \mathrm{n}$ In Where $\mathrm{q}_{\mathrm{e}}$ is the equilibrium amount of solute adsorbed per unit weight of adsorbent in $\mathrm{mg}^{-1}$ of clay; $\mathrm{C}_{\mathrm{e}}$ is the equilibrium organic pollutant concentration in aqueous phase in $\mathrm{mg} \mathrm{l}^{-1}, \mathrm{q}_{\mathrm{m}}$ is the $\mathrm{q}_{\mathrm{e}}$ for a complete monolayer in $\mathrm{mg} \mathrm{g}^{-1}, \mathrm{k}_{\mathrm{L}}$ is a constant related to the affinity of the binding sites and energy of adsorption in $1 \mathrm{mg}^{-1}, \mathrm{k}_{\mathrm{F}}$ and $\mathrm{n}$ are constants related to the adsorption capacity and intensity of the adsorbent respectively.

However, the equilibrium data for naphthalene over the concentration range studied at $298 \mathrm{~K}$ was correlated with Langmuir isotherm model by plotting $\mathrm{C}_{\mathrm{e}} / \mathrm{q}_{\mathrm{e}}$ against $\mathrm{C}_{\mathrm{e}}$. Linear plots obtained are shown below

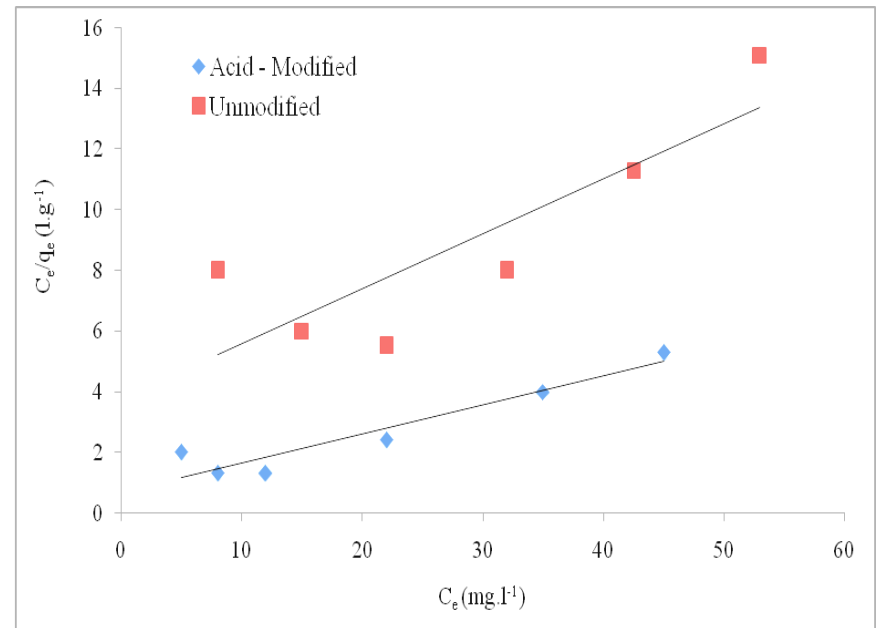

Fig 8: Langmuir plot for removal of naphthalene at $298 \mathrm{~K}$

The Langmuir model parameters $\mathrm{q}_{\mathrm{m}}$ and $\mathrm{k}_{\mathrm{L}}$ and the statistical fits of the adsorption data to this model are given in Tab. 3 below: 
Tab. 3: Isotherm model parameters for adsorption of naphthalene onto acid - modified and unmodified bentonite at $298 \mathrm{~K}$

\begin{tabular}{|c|c|c|}
\hline $\begin{array}{l}\text { Model } \\
\text { Parameters }\end{array}$ & $\begin{array}{l}\text { Acid - } \\
\text { Modified } \\
\text { bentonite }\end{array}$ & $\begin{array}{l}\text { Unmodified } \\
\text { bentonite }\end{array}$ \\
\hline \multicolumn{3}{|l|}{ Langmuir } \\
\hline$q_{e}\left(m g ~ g ~^{-1}\right)$ & 9.00 & 4.00 \\
\hline$K_{L}\left(L \mathbf{~ m g}^{-1}\right)$ & 0.14 & 0.05 \\
\hline$q_{m}\left(m^{-1}\right)$ & 10.52 & 5.56 \\
\hline $\mathbf{r}^{2}$ & 0.90 & 0.71 \\
\hline \multicolumn{3}{|l|}{ Freundlich } \\
\hline$K_{F}\left(L^{-1}\right)$ & 1.32 & 0.31 \\
\hline n & 1.81 & 1.45 \\
\hline $\mathbf{r}^{2}$ & 0.69 & 0.75 \\
\hline
\end{tabular}

The Langmuir model adequately described the adsorption process with $r^{2}$ values of 0.997 and 0.993 for acid - modified and unmodified bentonite samples. This implies that the sorption of naphthalene onto acid - modified and unmodified clay samples followed a monolayer formation. The result of the $\mathrm{q}_{\mathrm{m}}$ $\left(\mathrm{mg} \mathrm{g}^{-1}\right.$ ) parameter suggested that the monolayer capacity of the acid - modified was greater than unmodified.

On the other hand, a plot of In $\mathrm{q}_{\mathrm{e}}$ against In $\mathrm{C}_{\mathrm{e}}$ (Figure 9) was linear, though over a limited region of $\mathrm{C}_{e}$ which enabled determination of the constants $\mathrm{k}_{\mathrm{F}}$ and $n$.

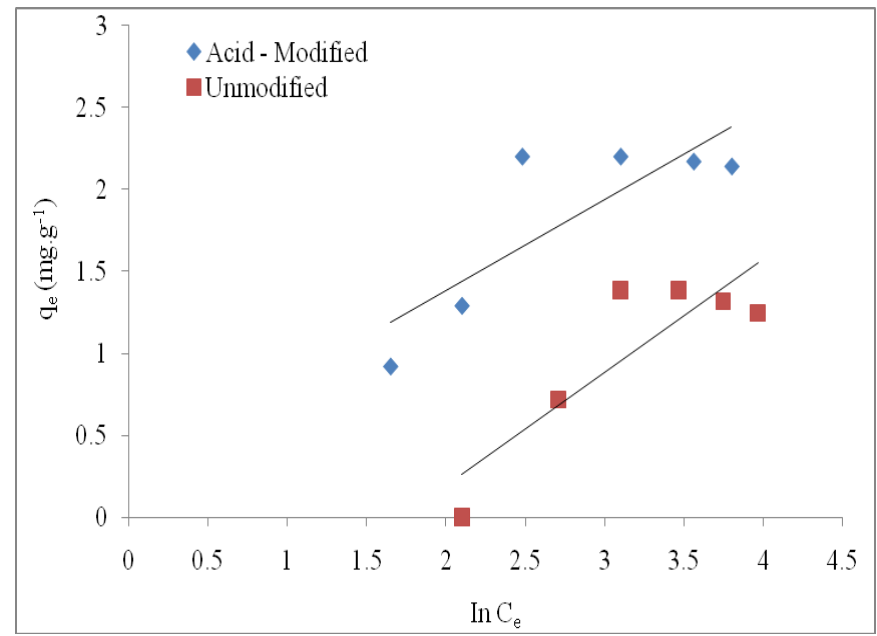

Fig 9: Freundlich plot for removal of naphthalene at $298 \mathrm{~K}$

The Freundlich constants $\mathrm{k}_{\mathrm{F}}$ and $\mathrm{n}$ were however calculated and the values are given in Tab. 3. The numerical values of $\mathrm{n}$ (between 2 and 10) indicate the adsorption capacity was only slightly suppressed at lower equilibrium concentrations.

Conclusion: The results obtained revealed that the adsorption capacities of modified and unmodified bentonite clay samples were observed to be dependent on concentration, contact time and $\mathrm{pH}$. Maximum adsorption capacities of $10.52 \mathrm{mg} \mathrm{g}^{-1}$ and $5.56 \mathrm{mg} \mathrm{g}^{-1}$ were obtained for modified and unmodified bentonite clay samples respectively. The adsorption process followed a monolayer formation. The kinetics of the adsorption process followed pseudo - second - order equation. The results indicated that acid - modified bentonite clay mineral can be a promising adsorbent for the removal of naphthalene (PAH) from aqueous solutions and contaminated waste waters.

Competing interest: Author has declared that no competing interests exist.

\section{REFERENCES}

Abia, A.A., Asoquo,E.D and Lawal, I.G. (2007). Comparsion of kinetics models for the sorption of Lead (II) ion from aqueous solutions using unmodified and thioglycolic acid modified guinea corn wastes, Indian J. of Sustain, Engr \& Green Chem., 2 (2): 1-9.

Cabal, B., Ania, C.O., Parra, J.B and Pis, J.J. (2009). Kinetics of naphthalene adsorption on an activated carbon: Comparison between aqueous and organic media, Chemosphere, 76: 433 - 438.

Fetzer, J.C. (2000). The Chemistry and Analysis of the Large Polycyclic Aromatic Hydrocarbons; John Wiley \& Sons, Inc., New York, USA, 27(2): 143 .

Freundlich, H. (1906). Colloid and Capillary Chemistry, Methuen, London, 37.

Ho, Y.S and Mckay, G. (1998). Kinetic models for the sorption of dye from aqueous solution by wood, J. Environ. Sci. Health Part B: Process Safety Environ. Protect., 76(B2): 183 - 191. 
Ivan, S and Velimir, P. (1998). The Colloid and Surface Chemistry of Clays in Natural Waters, CCACAA, 71(4): 1061-1074.

Lagergren, S. (1898). Zur theorie der sogenannten adsorption geloster stoffe, Kungliga Svenska Vetenskapsakademiens, Handlingar, 24: 1 - 39.

Langmuir, I. (1918). The adsorption of gases on plane surfaces of glass, mica and platinum, J. Am. Chem. Soc., 40: 1361-1403.

Makhoukhi, B., Didi, M.A., Villemin, D and Azzouz, A. (2009). Acid activation of Bentonite for use as a vegetable oil bleaching agent, J. Grassy Aceites, 60(4): 343-349.

Milhome C.M. (2008). Sources of PAHs, J. Ann. Chem. Phys., 21: 58-71.

Mohammed, M.I., Saleh, N.J., Isamael, R.M., Hussein, L.M., Manuiel, $\mathrm{N}$ and Mohmoud, A. (2007). Activation of Iraqi bentonite powder with $\mathrm{H}_{2} \mathrm{SO}_{4}$ with application in oils bleaching. Dept of chemical Engineering, University of Tech., Baghdad Iraq, 32-45.
Okoye, I.P and Obi, C. (2011). The adsorption dynamics of heavy metal ions onto titaniumpillared and unpillared bentonite clays, Journal of Nigerian Environmental Society, 5 (5): 22-28.

Ozer, L. (2008). Solubility reactions study of PAHs, J. Ann. Chim. Phys., 21: 28-51.

Sparks, D.L. (1999). Kinetics and mechanisms of chemical reactions at the soil mineral/water interface, in: Sparks, D.L. (Ed.), Soil Physical Chemistry, CRC Press, Boca Raton, FL, $135-192$.

Weber Jr, W.J., and Morriss, J.C. (1963). Kinetics of adsorption on carbon from solution, J. Sanitary Eng. Div. Am. Soc. Civ. Eng., 89: 31 - 60. 